BULLETIN Bulletin hispanique

HISPANIQUE Université Michel de Montaigne Bordeaux

$110-2 \mid 2008$

Varia

\title{
Luces y sombras de la tradición grecolatina en los ensayos de Francisco Bilbao Barquín
}

\section{Minerva Alganza Roldán}

\section{OpenEdition}

\section{Journals}

Édition électronique

URL : http://journals.openedition.org/bulletinhispanique/815

DOI : 10.4000/bulletinhispanique.815

ISSN : 1775-3821

Éditeur

Presses universitaires de Bordeaux

Édition imprimée

Date de publication : 1 décembre 2008

Pagination : 643-679

ISBN : 978-2-86781-543-0

ISSN : 0007-4640

Référence électronique

Minerva Alganza Roldán, « Luces y sombras de la tradición grecolatina en los ensayos de Francisco Bilbao Barquín », Bulletin hispanique [En ligne], 110-2 | 2008, mis en ligne le 01 décembre 2011 ,

consulté le 19 avril 2019. URL : http://journals.openedition.org/bulletinhispanique/815 ; DOI :

10.4000/bulletinhispanique.815 


\title{
Luces y sombras de la tradición grecolatina en los ensayos de Francisco Bilbao Barquín*
}

\author{
Minerva Alganza Roldán \\ Universidad de Granada
}

Cet article identifie et commente les allusions à l' histoire, à la mythologie et à la littérature de la Grèce et de Rome dans l'ensemble des essais de Francisco Bilbao, en suivant le cours de sa biographie et l'évolution de sa pensée. Pour ce romantique l'Antiquité devient une référence constante dans son analyse critique de la situation au Chili et en Amérique latine.

En este artículo se identifican y comentan las alusiones a la historia, la mitología y la literatura de Grecia y Roma en el conjunto de los ensayos de Francisco Bilbao, siguiendo el curso de su biografía y la evolución de su pensamiento. Para este romántico la Antigüedad llega a ser una referencia constante en su análisis crítico de la situación de Chile y de América latina.

This article identifies the references made to ancient Greek and Roman history, mythology and literature in Francisco Bilbao's collection of essays and discusses upon them, following the course of his biography and the evolution in his thinking. Antiquity becomes for this Romantic a constant reference in his critical analysis of the situation in Chile and Latin America.

Mots-clés : Francisco Bilbao - Tradition classique - Pensée politique - Essais Chili - XIX ${ }^{\mathrm{e}}$ siècle.

* Un resumen de este estudio, junto con una antología de textos, fue presentado como ponencia en el XVII Coloquio Internacional de Filología Griega: La tradición clásica en la literatura española e hispanoamericana del siglo XIX, organizado por la UNED y que se celebró en Madrid los días 1, 2 y 3 de marzo de 2006.

$B H i$, Tome 110, n 2 - décembre 2008 - p. 643 à 679. 
$\mathrm{E}$ L 18 De SEPTIEMBre de 1810, ante el vacío de poder provocado por la invasión napoleónica de España, se constituyó en Santiago de Chile la primera Junta Nacional de Gobierno, germen de la Independencia proclamada por Bernardo O’ Higgins el 12 de febrero de 1818. Mientras las minorías ilustradas esperaban que la emancipación de la metrópoli alumbrara un Orden Nuevo siguiendo la estela de las Revoluciones francesa y americana, los estamentos que habían sostenido al bando realista, se esforzaban en mantener sus privilegios en el marco de la naciente República. La consecuencia fue la polarización de las clases dirigentes en torno a los partidos conservadores («pelucones») y liberales («pipiolos»), cuyo antagonismo se plasma en los varios textos constitucionales e intentos de golpe de estado que conoce el país entre 1823 y 1828 . Al ańo siguiente estalla la primera guerra civil del Chile republicano, que se salda con la victoria de los conservadores y la dictadura de Diego Portales, cuyo régimen fue institucionalizado por la Constitución de 1833. Portales anuló las confiscaciones de los bienes de los mayorazgos y de la Iglesia, y ejerció una dura represión contra el bando liberal, poniendo en evidencia que el Antiguo Régimen, lejos de desaparecer, sólo se había revestido de ropajes republicanos.

Así pues, una vez alcanzada la Independencia, las elites ilustradas observan la imposibilidad de instaurar de manera inmediata el imperio de las Luces en el Nuevo Mundo, tanto por la fortaleza demostrada por la reacción, cuanto por su propia debilidad, y entre los intelectuales se abre un animado debate no sólo sobre las causas del fracaso, sino también acerca de las estrategias para la toma del poder. De ahí la importancia asignada a la formación de los jóvenes y a la creación de una opinión pública, a través de instituciones educativas, de periódicos y revistas, donde florece el ensayo, un género especialmente adecuado para la exposición de puntos de vista sobre las cuestiones sociales y para la publicidad de las ideas reformadoras ${ }^{1}$.

En Chile este proyecto histórico heredero de la Ilustración se materializa en la "Generación» o «Movimiento literario» de 1842, año de la fundación de la Universidad, cuyo primer Rector fue Andrés Bello, y de la «Sociedad de Literatura de Santiago", auspiciada por un ilustre liberal, José Victorino Lastarria. En su discurso de aceptación de la presidencia de la Sociedad Lastarria se dirige a los presentes, en su mayoría discípulos suyos del Instituto Nacional, diciendo: "Vosotros tenéis mis ideas y convenís conmigo en que nada será Chile, la América toda, sin las Luces [...] Hemos tenido la

1. Una visión de conjunto en J. L. Gómez Martínez, "Pensamiento iberoamericano del siglo XIX», Historia de la literatura hispanoamericana. Siglo XIX, Madrid: Cátedra, 1987, p. 399-416. 
fortuna de recibir una mediana ilustración; pues bien, sirvamos al pueblo, alumbrémosle en su marcha social para que nuestros hijos le vean un día feliz, libre y poderoso" ${ }^{2}$. En calidad de Secretario de la entidad había presentado el acto un joven, Francisco Bilbao, quien, siguiendo los dictados del maestro, no tardará en irrumpir en la escena pública.

La vida y la obra de Francisco Bilbao Barquín ejemplifican como pocas las vicisitudes de Hispanoamérica en la primera mitad del siglo XIX, cuando se constituyen y consolidan las nuevas naciones en el marco de un debate ideológico sobre la propia identidad, que partiendo de la Ilustración, transita por el movimiento romántico hasta desembocar en el Positivismo. Durante toda su existencia Bilbao defendió la necesidad de una transformación radical no sólo de Chile sino de toda América con ardor y absoluta entrega, lo que le ha valido los calificativos de "romántico revolucionario», «republicano místico" y "precursor del socialismo utópico» en las historias del pensamiento hispanoamericano ${ }^{3}$.

La gran empresa generacional de la emancipación política y cultural de América conllevaba la revisión crítica tanto del pasado español, cuanto de los modelos contemporáneos -Europa y los Estados Unidos de Norteamérica-, argumentos ambos para los cuales Bilbao trae a colación temas y personajes de la Antigüedad. Por otra parte, las referencias grecolatinas se van haciendo cada vez más frecuentes en sus ensayos, hasta devenir un componente notable en la exposición de su ideario, cuestión ésta que abordaremos al hilo de su biografía y de la evolución de su pensamiento ${ }^{4}$.

2. J. V. Lastarria, Obras, edición, selección y prólogo de L. E. Delano, México D. F.: Ediciones de la Secretaría de Educación Pública, 1944, p. 5-6.

3. Además de los tratamientos panorámicos de L. Zea (El pensamiento latinoamericano, Barcelona: Ariel, $1976^{3}$ ) y A. Roig (Teoría y crítica del pensamiento latinoamericano, México: FCE, 1981), las monografías de referencia son: A. Donoso, El pensamiento vivo de Bilbao, Santiago: Nascimento, 1940; J. Sepúlveda Rondanelli, Francisco Bilbao. Precursor del socialismo. Bosquejo de su vida, de sus obras y de su tiempo. Buenos Aires: Ediciones Boccanegra, 1971.

4. Las Obras Completas de Francisco Bilbao (Buenos Aires, 1866) fueron preparadas por su hermano, el novelista y político Manuel Bilbao. Pedro Pablo Figueroa publicó otras Obras Completas en cuatro tomos (Santiago de Chile: Imprenta «El Correo», 1897-1898), sobre las que se basa la más reciente edición de los principales ensayos: F. Bilbao, El Evangelio Americano, Selección, prólogo y bibliografía de A. Witker y Cronología de L. Benavides, Caracas: Biblioteca Ayacucho, 1988. 


\section{La herencia latina de la colonia: Sociabilidad chilena}

Con sólo once años Francisco conoció por primera vez el destierro5. Hubo de abandonar Chile para reunirse en Perú con su padre, un destacado representante de la oposición al régimen de Portales. En Lima realizó estudios de ciencias exactas, astronomía y música, y de regreso a Santiago en 1839 ingresó en el Instituto Nacional, donde cursó leyes, latín y filosofía con Andrés Bello, Lastarria y Vicente Fidel López, respectivamente. El ambiente familiar proclive a las novedades y a la libertad de pensamiento favoreció su temprana afición a la lectura, empezando por La Araucana de Ercilla, el libro junto a los Evangelios que más le influyó a lo largo de su vida, y continuando con Voltaire, Rousseau y Cousin, hasta encontrarse con la obra de Lamennais, cuya crítica del catolicismo marcará definitivamente su trayectoria ${ }^{6}$. Con tal bagaje Bilbao se incorporó al debate político en 1844 mediante el ensayo "Sociabilidad chilena»" de El Crepúsculo, la revista fundada en 1843 por Lastarria como órgano de la Sociedad de Literatura de Santiago.

En este escrito juvenil Bilbao realiza una disección crítica de la sociedad chilena, señalando con dedo acusador a quienes consideraba los máximos responsables de la traición a los principios de libertad, igualdad y justicia que habían animado la causa de la Independencia; a saber, los residuos del Antiguo Régimen, con la Iglesia católica a la cabeza, que para mantener su monopolio de la riqueza y del poder, ejercían un férreo control sobre las instituciones y las costumbres. Una vez efectuado el diagnóstico, las raíces del mal se hallan en la herencia española, ese pasado que había convertido a Hispanoamérica en un baluarte medieval frente a la Modernidad representada por la Europa revolucionaria. Este rechazo a España, una de las antinomias fundamentales del pensamiento hispanoamericano decimonónico, había sido expresado de manera radical por Lastarria en su discurso programático de la "Generación de 1842»: "Apenas ha amanecido para nosotros el 18 de septiembre de 1810, estamos en la alborada de nuestra vida social, y no hay un recuerdo tan sólo que nos halague, ni un lazo que nos una a lo pasado

5. Había nacido en Santiago de Chile, el 9 de enero de 1823.

6. Para la biografía remitimos al prólogo de Witker en la edición citada (p. ix ss.), y a R. López Muñoz, La salvación de América. Francisco Bilbao y la intervención francesa en México, México D. F.: Centro de Investigación Científica, 1995, p. 44-63.

7. Sobre el contexto de la «sociabilidad» de Bilbao véase J. Poblete, «Lectura de la sociabilidad y sociabilidad de la lectura: la novela y las costumbres nacionales en el siglo XIX», Revista de Critica Literaria Latinoamericana, 52, 2000, p. 13-22. 
antes de aquel día. Durante el coloniaje no rayó jamás la luz de la civilización en nuestro suelo» ${ }^{8}$.

El objetivo último de "Sociabilidad chilena» se hace patente desde su encabezamiento ("Descends du haut des cieux, auguste Vérité!» Voltaire), mientras que una cita evangélica ( $\mathrm{Voz}$ oída en Ramá, lloro y mucho lamento») $)^{9}$ tiñe de tonos dramáticos la primera parte, que se inicia así ${ }^{10}$ :

Nuestro pasado es la España. La España es la Edad Media. La Edad Media se componía en alma y cuerpo del catolicismo y de la feudalidad. Examinémosla separadamente. Esa sociedad así llamada, compuesta con los resultados de la civilización romana, idealizada por la religión católica y renovada por las costumbres originales de los bárbaros, forma el núcleo, el nudo que une al mundo antiguo con el mundo moderno. Roma deja su legislación, su industria y la mitología. El catolicismo, la filosofía antigua, los mitos orientales con el colorido de la revelación, pero con una perfección notable. Los bárbaros, la espontaneidad de sus creencias y la exaltación de la individualidad. Reflexión, fe, espontaneidad; Roma, Oriente, los bárbaros, he allí los elementos. Se chocan, la sangre corre, pero el bárbaro hecho católico triunfó (p. 59).

Al contrario de Andrés Bello, quien inclinaba la balanza a favor de España ${ }^{11}$, en opinión de Bilbao la impronta civilizadora de Roma resultó

8. J. V. Lastarria, op. cit., p. 7.

9. Se trata, respectivamente, de La Henriade (I, 7) y de la alusión a la profecía de Jeremías en el episodio de la matanza de los Inocentes (Mateo 2, 18).

10. Las páginas entre paréntesis remiten a la versión primera: F. Bilbao, «Sociabilidad chilena», El Crepúsculo, Núm. 2. Tom. 2, Santiago $1^{\circ}$ de junio de 1844, p. 57-90 [digitalizada en Memoria chilena. Portal de la cultura de Chile: www. memoriachilena.cl.]. En éste y los demás ensayos hemos aplicado las actuales normas ortográficas y corregido las erratas. Sin embargo, en la trascripción de nombres propios grecolatinos mantenemos la grafía usada por nuestro autor. Asimismo, en las citas literales respetamos las cursivas, mayúsculas y entrecomillados del original.

11. Como respuesta a la «Memoria presentada a la Universidad en sesión solemne del 22 de septiembre de 1844 por don José Victorino Lastarria», el ilustre polígrafo argumenta: «El despotismo de los emperadores de Roma fue el tipo del gobierno español en América [...] pero a vueltas de esas semejanzas odiosas hay otras de diverso carácter. La misión civilizadora que camina, como el sol, de oriente a occidente, y de que Roma fue el agente más poderoso en el mundo antiguo, la España la ejerció sobre un mundo occidental más distante y más vasto [...] Hasta en las cosas materiales presenta algo de imperial y de romano la administración colonial de España. Al gobierno español debe todavía la América todo lo que tiene de grande y espléndido en sus edificios públicos [...] y téngase presente que para construcción se erogaron con liberalidad las rentas de la corona, y no se impusieron los pechos y los trabajos forzados 
anulada por esa conjunción de catolicismo y barbarie, que hizo de la escolástica el instrumento de su perpetuación:

La educación lógicamente estaba encomendada a los conventos. Así se explica también el imperio de Aristóteles en la Edad Media. Aristóteles era entonces la lógica, es decir la deducción de los principios que se daban. La escritura y las doctrinas de los doctores y concilios era lo intocable, lo que se prohibía analizar [...] Helo allí, el catolicismo, ese cuerpo gigánteo que aferró sus garras en la Europa, dejando un templo en cada huella, he allí el genio misterioso de la montaña del simbolismo que lanzaba el rayo del anatema contra toda frente audaz que le encaraba; he allí el templo sombrío que inspiraba su terror al que pisaba sus umbrales (p. 65).

Aunque en un ensayo posterior Bilbao apoyará tal análisis en la autoridad de Lamennais ${ }^{12}$, su crítica al escolasticismo dogmático, en cuanto negación de la libertad de pensamiento, coincide con la valoración de su maestro Lastarria ${ }^{13}$ y con Feijoo, quien había proclamado: «Así yo, ciudadano libre de la República Literaria, ni esclavo de Aristóteles ni aliado de sus enemigos, escucharé siempre con preferencia a toda autoridad privada lo que me dictaren la experiencia y la razón» ${ }^{14}$.

El espíritu tenebroso del catolicismo feudal viajó en los barcos españoles hasta América y se impuso mediante el control ejercido por la Iglesia de la familia y la educación. Así, mientras la institución del matrimonio indisoluble reprimía los instintos naturales de muchachas y muchachos, sus

con que Roma agobiaba a los provinciales para sus caminos, acueductos, anfiteatros, termas y puentes». Nuestra cita remite a «Investigaciones sobre la influencia de la conquista y del sistema colonial de los españoles en Chile», en Antología de Andrés Bello. Prólogo y Selección de R. Esteban Scarpa, Santiago de Chile: Fondo Andrés Bello, 1970, p. 83.

12. Menciona, en concreto, Des maux de l'Église: cf. F. Bilbao, El Evangelio Americano, Buenos Aires: Imprenta de la Sociedad Tipográfica Bonaerense, 1864, p. 47.

13. Lastarria, op. cit., p. 10: «España [...] hizo crimen del cultivo de las bellas artes y las ciencias que no se presentaban guarnecidas con los atavíos embarazosos del escolasticismo"; idem, p. 67: «Enseñemos la Historia, la Filosofía, la Moral, el Derecho, las Ciencias políticas, no bajo las inspiraciones del dogma de la fuerza, del dogma de la monarquía latina, del imperium unum que rige la conciencia y la vida en Europa, sino bajo las del nuevo dogma de la democracia».

14. En el «Discurso décimo tercero» (XI, 35) del Teatro crítico universal. Sobre su influencia en las antiguas colonias, véase A. Millares Carlo, «Feijoo en América», Cuadernos hispanoamericanos, 3, 1943, p. 139-160. 
mentes eran prisioneras de una escuela anclada en las disciplinas clericales y enemiga del libre albedrío y la curiosidad científica:

La educación consiste en 6 años u 8 de latín (misericordia señor), unos 4 de filosofía escolástica y otros tantos de teología. Si pasan de las 4 reglas de aritmética, es mucho; si saben lo que hay del otro lado de los Andes, si saben que andamos alrededor del sol, es mucho. Los frailes y clérigos son maestros y la bofetada, el insulto grosero, o el azote son los medios correctivos. ¡Mirad la dignidad individual! (p. 66).

La identificación del latín con la cultura del Antiguo Régimen explica que para expresar la unidad indisoluble de catolicismo y monarquía, Bilbao recuerde la fórmula tradicional de legitimación del poder: «La autoridad es la fuerza, y la fuerza es la autoridad. El rey viene de Dios (REX GRATIA DEI), es su brazo, y el papa la inteligencia divina en la tierra. Conque: esclavos del gobernador; el gobernador del rey y el rey del papa (p. 67)» ${ }^{15}$.

La segunda parte del ensayo, bajo el epígrafe de "Revolución», plantea la urgencia perentoria de romper con el pasado para incorporarse a la nueva era inaugurada por Francia. La evocación de esta encrucijada de la historia de la humanidad yuxtapone el episodio bíblico de la expulsión del Paraíso con otros tomados de la mitología clásica y la historia de Roma: "He allí pues en esa fe, el círculo de fuego que guarda querubín con su espada aterradora. He allí los pilares de Hércules del pensamiento: he allí el Rubicón del catolicismo, de la Edad Media. ¿Pero faltará un genio, un Colón, un César del pensamiento que lo rompa? (p. 70)» ${ }^{16}$.

En este contexto, Bilbao expone un concepto central en su ideario: que el catolicismo, en realidad, deforma la religión verdadera, aquella cuyo Dios no sólo no necesita esclavos, sino que ha concedido al hombre la capacidad de pensar y de dudar. Esta religión de la Razón y la Libertad, con profetas como Lutero, Descartes, Voltaire y Rousseau, alumbró por vez primera en el siglo glorioso de la Enciclopedia y los descubrimientos científicos ${ }^{17}$, y su luz

15. Más adelante, para el carácter revolucionario de la Independencia de Chile se sirve del latinismo «a SEDIBUS IMIs, de raíz (p. 73)», quizá eco de Virgilio (Eneida 1, 84).

16. El serafín de espada flamígera, guardián de las puertas del Paraíso aparece en Génesis 3, 24. Entre los testimonios antiguos sobre las «Columnas de Hércules», véanse Píndaro, Ístmica IV, 30; Diodoro de Sicilia IV, 18.5 y Apolodoro, Biblioteca, II, 5.10. Al pasar el Rubicón en el 49 a.C., César era consciente de que trasgredía la ley romana, de ahí su célebre frase: «Alea iacta est (la suerte está echada)»: Suetonio, Iul. 31; 32.

17. «iEspectáculo grandioso! ¡Trabajo gigánteo! ¡Babel del genio! ¡Siglo XVIII! (p. 71)». 
alcanzó hasta la primera etapa del Chile independiente, singularmente durante el bienio liberal del general Pinto (1827-1829):

En esta época fue cuando vino a Chile este número de extranjeros que nos ha producido tantos bienes [...] La filosofía que nos había dado libertad, es introducida entre nosotros, libre como su esencia. El derecho político y civil, estas dos ciencias indispensables por la armonía social e individual, fue entonces cuando se supo lo que eran entre nosotros. El escolasticismo y el código español con todos sus secuaces, temblaron al análisis que los devoraba (p. 77) ${ }^{18}$.

No obstante, las fuerzas reaccionarias con el apoyo eficaz de la Iglesia propiciaron esa resurrección del pasado que nuestro joven revolucionario invita a destruir:

La educación allí está encadenada a la síntesis antigua, recargada de prácticas y falta del conocimiento relativo de la vida social y humanitaria. La síntesis antigua que debía regenerarse se propaga. Los libros que se dan a las escuelas son antiguos y relativos al tiempo pasado. Digamos pues si en las cortas observaciones que llevamos no va envuelto el carácter conservador y retrógrado de la administración actual. En educación, en culto, en hacienda y en régimen interior. Esto se puede decir que no es más que un pequeño programa de oposición (p. 85-86).

El programa de gobierno se enuncia como los principios de una nueva religión, la «religión científica», y exige de sus prosélitos que estén dispuestos a afrontar el destino de los rebeldes de cualquier tiempo, como los Titanes y los Gigantes de la mitología, y los mártires cristianos:

Acordémonos siempre en los momentos de la tribulación moral, en aquellos momentos en que la indiferencia asoma su satánica sonrisa, de ese poder inmenso que sentimos, de ese poder terrible en su congoja y la conciencia de ese poder nos dirá que somos algo. Este algo es la vida, es la revelación que nos dice que llevamos una carga y que el ser que nos la ha dado, nos glorifica al encomendarnos una obra gigántea. Entonces volvemos a la vida y alzándonos titánicos con el

18. Bilbao se refiere al español José Joaquín de Mora y al venezolano Andrés Bello, el cual desde su llegada a Santiago en 1829 había asumido la tarea de formar a las elites del país. 
conocimiento de la libertad tempestuosa que encerramos, elevaremos a Dios el himno de la fe del martirio y pasaremos esta vida con la frente erguida rebotando el rayo y con nuestras miradas desafiando la nube que lo lanza (p. 90).

Su furibundo ataque al clero por sustentar a un régimen autoritario, así como su llamada a subvertir el orden establecido, tuvieron una respuesta inmediata y fulminante. A los pocos días de publicarse la «Sociabilidad chilena», Bilbao fue procesado por «sedición, inmoralidad y blasfemia». El acto del juicio derivó en un auténtico motín en la sala y en la calle, con un acusado desafiante que asumió su propia defensa, quedó libre en el acto, al pagarse mediante suscripción pública la multa que le había sido impuesta, y salió del tribunal a hombros de sus partidarios. La revista El Crepúsculo fue definitivamente clausurada y Bilbao, expulsado del Instituto Nacional sin terminar sus estudios, se trasladó a Valparaíso, donde ejerció fugazmente el periodismo, ya que obligado por las circunstancias, en octubre de 1844, zarpó rumbo a Europa ${ }^{19}$.

\section{Carácter ejemplar de la Antigüedad: Los boletines del espiritu}

A partir de 1845 reside en París y se matricula en el prestigioso Collège de France donde asiste a los cursos de filosofía e historia impartidos por Edgard Quinet y Jules Michelet. Su magisterio, que pronto deviene amistad, resultará trascendental para la evolución del pensamiento de Bilbao y, sin duda, repercutirá notablemente en su conocimiento y valoración de la Antigüedad clásica ${ }^{20}$. Además, frecuenta la compañía de su admirado Lamennais, de quien traduce algunas obras, y de otros extranjeros, en su mayoría refugiados políticos provenientes de toda Europa, de África y Asia. Entre octubre de 1847 y junio de 1848 visita varias capitales del Imperio austrohúngaro y recorre buena parte de Italia, Roma incluida. Cuando en junio de 1848 estalla la Revolución, Bilbao combate junto a Quinet en las barricadas de París, pero el triunfo de los reaccionarios acrecienta sus deseos de volver a Chile, donde llega a principios de $1850^{21}$.

19. Sobre el juicio y su repercusión pública, véanse el «Prólogo» de E. Delano en la ya citada edición de Lastarria (p. xiii-xiv), además de R. López Muñoz, op. cit., p. 8-41.

20. Michelet, por ejemplo, se había doctorado en 1819 con una Tesis sobre las Vidas paralelas de Plutarco y había publicado en 1831 su conocida Histoire romaine.

21. Para los hitos biográficos de su primera estancia europea véase la ya mencionada «Cronología» de L. Benavides (p. 312); además, R. López Muñoz, op. cit., p. 51-53. 
Durante la travesía redacta los Boletines del espiritu, una especie de «diario» en el que vuelca sus pensamientos, y que entrega de inmediato a la imprenta ${ }^{22}$. El «Boletín I» se inicia con una anécdota sobre la fundación de Roma, calco casi literal de un pasaje de Tito Livio:

Cuando los Romanos hacían las primeras excavaciones para echar los cimientos del Capitolio, fue encontrada una cabeza humana, cuyo hallazgo los sacerdotes interpretaron prediciendo que Roma sería la cabeza del mundo y su pueblo el Pueblo Rey. En consecuencia el romano recibió el bautismo del Rey del Universo y la Roma del porvenir se encargó de realizar la profecía (p. 293) ${ }^{23}$.

Tales vaticinios, comenta Bilbao, son una especie de ley histórica aplicable a todos los pueblos y ciudades, por lo que, en cumplimiento de su destino, se impone "constituir la Roma universal cuyo capitolio sea la fraternidad de los pueblos y cuyo dios el padre del amor y no los iracundos Júpiter ni Jehová», sino de acuerdo con la máxima evangélica: «El primero de todos será el servidor de todos (p. 293)» ${ }^{24}$.

En el «Boletín III» se interroga acerca de las razones de su tristeza y las encuentra en sus dolorosos recuerdos del Continente que acaba de abandonar: la traición de los ideales cantados por La Marsellesa, las tierras de Italia convertidas en campos de guerra como en los días de César y de Napoleón, y entre tanta destrucción afloran las imágenes de su visita a Roma:

Y tú, Roma, osario de los pueblos, nacida para tu propia desesperación, bella en tu secular existencia, bella y bellísima en tus amontonadas ruinas, sublime en tus abandonados y silenciosos manes. Roma ¿qué eres Roma? Sombra fantástica que refleja únicamente la luz pálida del eclipse de la fuerza y de la gloria. No volveré a pisar tu Foro, ni la plaza de la revolución, ni veré los mundos históricos prediciendo los días del porvenir. No, no veré eso, porque bajo otro cielo, en otra

22. Nuestras citas de este opúsculo, publicado en 1850 , siguen el texto establecido por Witker, op. cit., p. 293-306, a cuya paginación remitimos.

23. Livio (1, 55, 3-5) sitúa el prodigio en el contexto de la ampliación del templo de Júpiter en el Capitolio en tiempos de Tarquinio el Soberbio. A partir de esta leyenda Varrón (De lingua latina, V, 7) explica la denominación del lugar: «Capitolinum dictum, quod hic, cum fundamenta foderentur aedis Iovis, caput humanum dicitur inventum (se llama Capitolio porque aquí, cuando se cavaban los cimientos del templo de Júpiter, se dice que fue encontrada una cabeza humana)», etimología con la que juega Bilbao en éste y otros pasajes.

24. Cf. Mateo 20, 24, 28. 
montaña y en otros valles tengo mi patria que es donde vi la primera luz. Y la patria es el altar del sacrificio en donde cada ciudadano debe ofrecer, en holocausto, su corazón (p. 295).

Una viva narración del célebre episodio de las Termópilas con su correspondiente exégesis forma el «Boletín X», subtitulado «El deber y el número» ${ }^{25}$ :

Jerjes avanza con un millón de soldados, mientras trescientos espartanos le esperan a pie firme. Retiraos, pues vais a morir inútilmente, les dice el egoísmo. El deber responde. Las fronteras de la patria se defienden con el valor del alma y no con el número ni la infamia. En la víspera del combate, Leónidas dice a sus compañeros: Mañana cenaremos en la mesa de la inmortalidad. Se acerca el enemigo, grita un centinela. No, dice Leónidas, somos nosotros que nos acercamos a ellos, mientras el ruido de los enemigos hacía temblar la tierra y la descarga de sus flechas ocultaba el sol. Y los héroes no se cuentan, y si fijan su propio número no cuentan el del enemigo ni tampoco el de los aliados que abandonan sus filas ni tampoco a los traidores que les atacan por la espalda. Combaten y mueren. Y ¿quién venció? Dios, la fraternidad, la libertad ¿Quién contó a sus enemigos, ni quién se aterra por el ruido de las turbas? En verdad que seríais inferiores a Leónidas y sus trescientos combatientes que murieron (p. 299).

El encomio de quienes antepusieron su deber a la superioridad numérica del enemigo, convirtiendo su derrota en el anticipo de la victoria final de los griegos, volverá a aparecer en ensayos posteriores. Su carácter ejemplar viene resaltado aquí por el paralelismo que se establece a continuación con otra batalla en la que aún venciendo el invasor, el español Valdivia, de poco le aprovechó, dado que cayó asesinado por la mano justiciera del indio Lautaro $^{26}$. Al fin y a la postre, reflexiona nuestro autor, la historia de la humanidad es un campo de batalla donde la ciencia y el amor se enfrentan a las tinieblas, batalla indecisa en la que la victoria final depende de la capacidad del heroísmo para imponer la luz ${ }^{27}$.

25. Véanse Heródoto VII, 219-228 y Diodoro de Sicilia XI, 4-11. Las alusiones a las Termópilas se convirtieron en lugares comunes de los oradores griegos, por ejemplo, Lisias (Epitafio, 30-33) e Isócrates (Panatenaico, 187).

26. El «Boletín XI» (p. 299) es trasunto del Canto III de La Araucana. En honor al tiranicida Francisco, Bilbao pensó llamar Lautaro a su único hijo, fallecido al poco de nacer.

27. Véase el «Boletín XIII» (p. 301). 
Todo el opúsculo, redactado en un tono efectista y mesiánico, está teñido de negros presagios, como si el autor barruntara que nada más publicarse sería excomulgado, cruel paradoja si tenemos en cuenta que los Boletines se cierran con el principal de los mandamientos de Jesús: «Ama a Dios sobre todas las cosas y a tu semejante como a ti mismo (p. 306)»" ${ }^{28}$.

\section{Luz de Grecia y sombras de Roma: Revolución en Chile y los mensajes del proscrito}

El 14 de abril de 1850 Bilbao fundó junto a liberales radicales y algunos obreros «La Sociedad de la Igualdad», organización que en pocos meses alcanzaría varios miles de afiliados, convirtiéndose en una grave amenaza para el gobierno autoritario de Montt, que la prohibió en noviembre de ese mismo ańo. El 20 de abril de 1851 el partido de la Igualdad encabeza la insurrección contra el gobierno y Bilbao vuelve a empuñar las armas, esta vez en las calles de Santiago. Una vez aplastado el levantamiento, huye de Chile disfrazado de fraile para nunca regresar ${ }^{29}$. Entre 1851 y 1855 reside en Perú, donde aparece Revolución en Chile y los mensajes del proscrito, recopilación de ensayos al hilo de lo acontecido en Chile, así como de la situación de Europa. En estos escritos se aleja de los postulados liberales y toma partido por una revolución cuyos protagonistas identifica con los trabajadores y las capas más humildes, proceso ideológico acompańado por una mayor presencia de temas grecolatinos ${ }^{30}$.

De hecho, el Prólogo, «A los proscritos», está encabezado por esta cita casi literal de Lucano ${ }^{31}$, «Causa victrix Diis placuit sed victa Catoni», que traduce: «La causa vencedora agradó a los Dioses, mas la vencida a Catón». Y continúa: «Hemos abrazado la causa de la revolución. Antheo siempre derribado, pero siempre en pie desde que toca la tierra, la revolución, vencedora en la inteligencia, no asentará radicalmente su victoria, sino tocando la tierra con la vara de Dios, la medida justicia, la Santa Igualdad (p. 4)».

28. La cita evangélica se corresponde con Mateo 22, 34, 40. Bilbao desembarcó en Valparaíso el 22 de febrero de 1850 y los Boletines aparecieron en Santiago un mes más tarde.

29. Sus restos mortales fueron trasladados desde Argentina a la patria en agosto de 1998.

30. Los ensayos del volumen se fechan a partir de 1851. Citamos por la primera edición: F. Bilbao, Revolución en Chile y los mensajes del Proscrito, Lima: Imprenta del Comercio, 1853 [digitalizada en Memoria chilena. Portal de la cultura de Chile: www.memoriachilena.cl.].

31. Cf. Farsalia 1, 128: «victrix causa diis placuit, sed victa Catoni». 
Sin duda, la simpatía por los vencidos explicaría la afinidad de Bilbao con el poeta latino, ratificada por la alusión mitológica ${ }^{32}$. Ahora bien, frente a la imagen clásica del monstruoso malhechor vencido por Hércules, este Anteo encarnaría el espíritu de resistencia frente al opresor. Tal es la empresa a la que el chileno, un proscrito, ha decidido dedicar su vida con plena conciencia de su dificultad, y que glosa con reminiscencias clásicas:

Grande es la causa, fuerte el enemigo. Tentación grandiosa para los que contando con la justicia, quieren ser partícipes de esa legión que muriendo en las Thermópilas, venció al Oriente enfurecido. Han pasado los días grandes, lo bello se ausenta, las epopeyas terminaron y el alma del hombre desciende la escala de los seres, bajo el peso del clima de corrupción que se forma sobre la tierra (p. 6).

En la «Introducción» al opúsculo afirma que la esencia de la humanidad es la libertad, apoyándose en un conocido aforismo ${ }^{33}$ : «Cambiaría o interpretaría el famoso verso de Terencio "Homo sum, et nibil humanum a me alienum puto». Hombre soy y nada de lo humano me es extraño. En estas palabras que violentan a la gramática sin duda, pero que expresan mi pensamiento individual y social, Homo sumus. Hombre somos (p. 14)». Sin embargo, la historia demuestra que el Bien convive con el Mal, circunstancia que, según Bilbao, explica el origen de las religiones, cuyos dogmas condicionan el conjunto de las instituciones y manifestaciones de la personalidad de los pueblos. Por ejemplo, dice, «Roma creyó que su destino era ser Roma en todas partes y se educó para la conquista (p. 16)». Por el contrario, la situación de Francia ilustraría la fuerza del enemigo y el que para emanciparse, América debe buscar su propio destino:

Madre de Descartes, e invocando al papa, madre de Voltaire, y acatando una parodia imperial, madre de Rousseau, y negando la revolución ¿iHasta cuando la Francia frustrará las esperanzas de los pueblos? Quizás sea esto una necesidad

32. Anteo, gigante nacido de Poseidón y Gea (la Tierra) e invulnerable mientras permanecía en contacto con su madre, fue vencido por Heracles, que buscaba el jardín de las Hespérides, tras levantarlo en vilo, episodio prolijamente tratado en la Farsalia (4, 590-660). Lucano inspiró a Dante (Divina Comedia XXXI, 112 ss.), un poeta varias veces aludido por Bilbao.

33. Terencio, Heautontimoroumenos, 77. Bilbao advierte que ha utilizado como «Introducción» su contestación a una carta de su amigo y correligionario Santiago Arcos, un fragmento de la cual transcribe. Arcos, que se encontraba encarcelado en Santiago de Chile tras el fracaso de la sublevación de 1851, respondió a la misiva el 29 de octubre de 1852. Sobre esta correspondencia, véase A. Witker, op. cit., p. xviii ss. 
porque parece que llega la hora de la abolición de toda tutela y que la providencia dijera a los pueblos: id, sed vosotros mismos vuestro Capitolio (p. 39)

imagen que retoma más adelante recordando las enseñanzas de Michelet: «El nuevo Capitolio, la nueva cabeza, que designará la mansión central de la historia moderna, se levanta en todo pueblo que se declara ser por sí mismo (p. 40)».

Cuando en el capítulo segundo de Revolución en Chile rememora los sucesos que lo llevaron al exilio, compara su peripecia con la de Perseo: «Todo se levantó contra mí y todo tembló. ¿Por qué? Porque fui verdad, porque el pasado entero se sintió sacudido en sus cimientos, porque toqué el corazón del enemigo, porque decapité con la palabra la capital del imperio esclavizado, porque hice resplandecer los albores de la ciudad nueva, porque la libertad afirmada será siempre la cabeza de Medusa contra todas las mentiras (p. 42)» ${ }^{34}$. Ecos mitológicos resuenan, asimismo, en la exposición de los factores naturales que condicionan la actitud sumisa de los chilenos: «La fisonomía del país es la de una musculatura titánica. Sucesión encadenada de pirámides sublimes, las cordilleras se levantan como la autoridad de la tierra, como catedrales de la naturaleza, como una adoración inmóvil y persistente del globo hacia la autoridad suprema (p. 44)».

A propósito de la influencia de las razas cuyo encuentro marcó el destino de la patria, Bilbao se ocupa de los conquistadores, haciendo uso de sus conocimientos de latín: «El español es el creyente. Su fe es ciega, se enorgullece de tener la fe del carbonero, credo quia absurdum (p. 48)» ${ }^{35}$. El dogmatismo religioso de los españoles explicaría, por otra parte, la organización despótica de la colonia, siguiendo los más rancios preceptos del derecho romano: «Distinción eterna entre noble y plebeyo, semejanza notable con la Ley de las doce Tablas: Adversus hostem aeterna auctoritas esto (hospes, hostis). Siempre hay autoridad contra el enemigo, y el enemigo era el huésped, el extranjero, el plebeyo, el hombre fuera de la ciudad social (p. 49)» ${ }^{36}$.

Bajo el título de "Los Mensajes del proscrito» la segunda parte del opúsculo recoge una miscelánea de artículos y breves ensayos, algunos de

34. En la ya mencionada edición de A. Witker (p. 68) se recoge una redacción diferente del pasaje: "porque evoqué las generaciones futuras, porque hice resplandecer los albores de la ciudad nueva, porque la libertad afirmada, aunque aislada, será siempre la cabeza de Medusa».

35. La expresión se suele atribuir a Tertuliano.

36. Juego etimológico a partir de Lex XII tab. 6.3, cuyo enunciado vuelve a repetir en posteriores ensayos. 
ellos publicados con anterioridad. Es el caso de "Necesidad de una Reforma», aparecido en Chile dos meses antes de la revolución de 1851, donde se llama al levantamiento popular para purificar a la patria de la podredumbre reaccionaria siguiendo el ejemplo del héroe antiguo: «saludemos al pueblo que ahogará las serpientes en su cuna como el Hércules de Grecia (p. 111)».

Menos circunstanciales resultan las alusiones a la Antigüedad clásica en «La Definición», cuya difusión en el periódico limeño El Comercio le había obligado a esconderse durante tres meses en la embajada de Francia en Perú, para escapar a la persecución gubernamental. Comienza destacando el paralelismo entre dos acontecimientos históricos trascendentales:

La caída del imperio romano por el brazo de los bárbaros y el espíritu del Evangelio, la caída del mundo monárquico y feudal al empuje de Francia y la filosofía. El Dios del mundo romano, monstruoso mosaico de todas las divinidades de la tierra, cedió su lugar a la unidad del Dios de los cristianos, y el Dios de la Edad Media, monarca despótico en el solio infalible del Vaticano bamboleó ante el Dios de la libertad, proclamado en el oráculo universal de la democracia (p. 117).

En ambos casos se estableció un duelo a muerte entre dos modelos irreconciliables de ser y de pensar, lucha marcada por derrotas y victorias, y también por sus mártires: «Sócrates y Jesucristo, Galileo y Voltaire, la Convención nacional y Napoleón he ahí las señales del sangriento itinerario (p. 117)» ${ }^{37}$. Ahora bien, matiza Bilbao, a diferencia del pasado, la revolución que se avecina, tiene como tribuno a la misma Providencia, y como protagonista a una humanidad que combate a favor de la fraternidad universal y la igualdad, guiada por la razón, y obedeciendo la ley de un Dios de amor y libertad. Y para significar la magnitud de la empresa acude a uno de sus símiles preferidos: «es el combate titánico que se renueva contra el soberbio Olimpo envejecido (p. 118)».

En tal encrucijada de la historia considera imprescindible una nueva definición de Dios, pues ya no bastan las nociones particulares que en épocas anteriores aportaba cada pueblo: «...el mundo griego sobre el verbo de Platón [...] El mundo moderno impulsa premisas, amontona sistemas como las olas de un océano que quisiera levantar sobre sus aguas el nuevo Cosmos, la nueva Venus, el Génesis filosófico de la libertad (p. 119)»38.

37. La consideración de Sócrates como antecedente del cristianismo y su comparación con Jesús es un tópico presente ya en el siglo III, por ejemplo en Justino (Apología I. 5; I.46).

38. El valor cosmológico del nacimiento de Venus, ampliamente explotado por la tradición europea desde el humanismo, se remonta en última instancia a Hesíodo (Teogonía 190 ss.), 
Para describir su siglo, Bilbao yuxtapone la imagen bíblica del Diluvio con las crisis proféticas de la Pitia y la ansiedad de un héroe homérico: «La humanidad se estremece sobre el trípode del infinito. Cual otro Ayax, invoca a la luz en la tribulación de la batalla (p. 140)» ${ }^{39}$. El componente clásico le sirve para simbolizar el carácter antagónico de las fuerzas en conflicto: «Comparad al hombre sublimado, según el Apolo Belvedere, con el hombre macerado de los anacoretas y veréis la diferencia que produce la confianza o el temor» (p. 121) ${ }^{40}$; y también para ensalzar la revolución: «Esta es nuestra causa, ciudadanos del universo y veis que es el nuevo Cosmos, la belleza misma produciendo al soplo de Dios (p. 121)».

La universalización del proceso también adquiere en Bilbao connotaciones mitológicas. Así, el paneslavismo sería «como la estatua de Jano» que «mira al pasado y al porvenir, mira al Oriente y al Occidente y precipita sus millones de hombres a una misteriosa confederación (p. 123)», mientras que en la América del Norte: «Nacionalidades diferentes, sistemas diversos, oposición de clases, organizaciones contradictorias, se han dado cita para resolver el problema. Es el sopor simbólico de Júpiter que espera el golpe de Vulcano para revelar el verbo (p. 128)» ${ }^{41}$. En este renacimiento del mundo, que Bilbao proclama a la manera bíblica ${ }^{42}$, la situación de Chile le recuerda el martirio de los primeros cristianos y el presidente Montt, al emperador saludado por los condenados a muerte: «morituri te salutant!» (p. 124).

La Antigüedad clásica, y especialmente Grecia, vuelven a utilizarse como exempla en el ensayo titulado "La Religión-Libertad», que con motivo del 18 de septiembre, aniversario de la Independencia, dedica a sus «compañeros proscritos». Afirma: «Todo lo que ha habido de grande, todo lo que dura y ha durado lleva el sello de la religión [...] himnos del heroísmo en la tierra de Minerva; culto de la patria, código de derecho en el Latio; catedrales de la Edad Media, epopeya de la revolución francesa (p. 160)». Sin embargo, el verdadero Dios, el de la humanidad toda y la libertad, es un Dios olvidado, que «trata de revelar sobre las ruinas de las civilizaciones y en medio del temblor que sacude a la tierra golpeada por el brazo del porvenir, como el cráneo de Júpiter, por el heroísmo de la Grecia (p. 160)». El hombre,

donde Afrodita emerge de la espuma del mar tras la castración de Urano.

39. Esta invocación a la luz del hijo de Telamón ocurre en su plegaria a Zeus de Ilíada XVII, 645 ss. Paradójicamente, en Sófocles (Ayax 398) cuando el héroe recupera la razón antes de suicidarse, llama a las tinieblas.

40. Bilbao podría haber visto la estatua durante su visita a Roma en 1848.

41. Alusión al conocido episodio del nacimiento de Atenea-Minerva de la cabeza de su padre.

42. «Fiat lux (haya luz)», dice en la página 127, eco de Génesis 1, 3. 
explica Bilbao, habría recibido de Dios la libertad, pero cayó y apagó este fuego sagrado. El sufrimiento derivado de esta caída se explica acudiendo a la filosofía de Platón: "No se llega a los Campos Elíseos, sin atravesar un infierno (p. 163)» ${ }^{43}$. Seguidamente ańade: «No es otro el problema de la libertad, no es otra la interpretación de aquel famoso nosce te ipsum de la sabiduría antigua. Conocerse a sí mismo, es creer en sí mismo. Conocerse y creer es tomar posesión de la libertad» ${ }^{44}$. No obstante, concluye,

las religiones y gobiernos de las repúblicas griegas y romanas han sido apariciones bellas aunque incompletas de la libertad religión. La ciudad, la patria, la ley, eran el dogma; el patriotismo, el civismo eran el culto. Y cuando Asia condensó sus fuerzas teocráticas para devorar la Grecia, entonces aprendió en las Thermópilas que las fronteras de la patria eran el dintel del templo de los griegos (p. 164).

La evocación del Imperio romano a propósito del presente aparece en varios pasajes de "La palabra de la Hungría» ${ }^{45}$. En aquel tiempo: «El mundo despavorido se arrodillaba ante el coloso romano. Los pueblos, las razas, las naciones, una a una venían a pasar bajo las horcas caudinas del imperio y la cabeza de Roma, el soberbio Capitolio llegó a ser la isla del orgullo en medio del océano de sangre, de la humanidad esclavizada (p. 193-194)» . La palabra de Jesús, el mensaje del amor, fue insuficiente ("dio su entraña a los leones en el Coliseo») y se hizo necesaria la espada de Atila («Vencedor de los vencedores de Roma, envolvió a las razas bárbaras y arrasando ciudades y naciones se precipitó sobre el Imperio»). Cuando a la llamada de la Revolución francesa, los húngaros se rebelaron, fueron aplastados por la Alianza de los reaccionarios, de los tiranos contemporáneos: «Nerón gozaba también ante la vista de Roma en el incendio [...] Tenéis el corazón de Nerón menos la audacia (p. 198)». Sin embargo, la historia también aporta razones para la esperanza, simbolizada en dos personalidades que cambiaron su curso:

\footnotetext{
43. El «Juicio de las almas» parece una elaboración de Platón a partir de temas órficos: véanse Fedón 11d-114c y Gorgias 523a -524a, donde se sitúa en la encrucijada del camino hacia la Isla de los Bienaventurados y el del Tártaro. El tema será retomado por Virgilio, uno de los clásicos más influyente en Bilbao.

44. Platón (Protágoras 343a ss.) recoge la máxima entre otras atribuidas a los «Siete Sabios» e inscritas en Delfos. La tradición griega suele atribuirla a Quilón de Lacedemonia, por ejemplo Diodoro de Sicilia (IX, 9-10), Pausanias (X, 24, 1) y la Antología Palatina (IX 366). Platón concede un amplio espacio en Alcibiades I (129 ss.) a la exégesis de su maestro. Para la expresión latina del lema socrático, véase Cicerón Tusc. 1, 52.

45. Ensayo dedicado a Lajos Kossuth, independentista húngaro que lideró la revolución de 1848.
} 
«Alejandro legó el Imperio al más digno, Jesucristo legó el mundo al más amante. Proscritos, preparaos a recoger la herencia del Imperio (p. 199)» ${ }^{46}$.

Bilbao recurre nuevamente al paralelismo con la Antigüedad en el folleto «Al 20 de julio Aniversario de la Independencia de la Nueva Granada». Cada vez que el Creador quiere sacudir a la humanidad envejecida, envía un héroe visionario -Cristo, Atila, Colón-, el cual «después de una desaparición en los abismos no surcados, se presenta como un Hércules del cristianismo, cargando un continente a sus espaldas, y mostrándolo al viejo mundo, le dijo: he aquí la tierra definitiva, he aquí los valles prometidos a la nueva Jerusalem de los mortales (p. 201)» ${ }^{47}$. En cuanto al periodo de la Independencia hispanoamericana, señala cómo las jóvenes naciones «embriagadas con la copa hirviente del porvenir entre las manos, tuvieron los delirios de los tiempos heroicos, y cual la pitonisa de los griegos temblaron, al pisar, al sentir que abordaban las mansiones de la libertad (p. 203)».

En otro ensayo conmemorativo, "Al 18 de septiembre, aniversario de la Independencia de Chile», el acontecimiento se enaltece mediante la evocación de un tema de profunda raigambre clásica, los Campos Elíseos:

Y al contemplarte en uno de tus aniversarios, joh libertad! nos sentimos ante la presencia del Tribunal Supremo que convoca a los pueblos a pedirles cuenta de su vida [...] y escuchamos tu palabra que sentencia y precipita al género humano a las regiones de la luz, a los Campos Elíseos prometidos, ese foro de los héroes (p. 213) [...] Tuyo es el porvenir, madre de la dignidad y de la gloria. Tuyos son los Campos Elíseos donde reposarán transfigurados los que te aman y te sirven (p. 219) ${ }^{48}$.

Por ello, aún a costa de ser acusados de herejes, los verdaderos patriotas deben persistir en la lucha por la democracia, "la espada de Damocles suspendida sobre la cabeza de todo despotismo (p. 221)» ${ }^{49}$.

46. Por añadidura, ambos habrían muerto a los 33 años.

47. La analogía entre Hércules y Jesucristo fue explotada por los primeros apologistas cristianos y reaparece en Erasmo: véase M. Simon, Hercule et le Christianisme, Estrasburgo, 1955.

48. Los Campos Elíseos son el lugar de los héroes en el Hades ya en la Odisea (IV, 563569) y en Platón la residencia de los sabios (Fedón 114 c.). En la tradición europea influyó sobre todo la versión de Virgilio que sitúa allí la morada de los justos (Eneida 5, 735).

49. La conocida anécdota entre Damocles y Dionisio de Siracusa aparece en Cicerón (Tusc. 5, 61-62). 
En "Diplomacia de la República», Bilbao invoca las grandezas de la historia de Grecia para alabar la política de Estados Unidos y, en concreto, la concesión de la ciudadanía a numerosos refugiados políticos europeos: «Estas son las victorias que fecundan, estas son las batallas que debe dar el espíritu nuevo y que rivalizarán con los de Marathón en su resultado (p. 230)» ${ }^{50}$. Por su magnanimidad la República norteamericana se muestra digna heredera de Roma ${ }^{51}$ :

Antiguamente hemos visto que el nombre de romano y la ciudadanía romana daba al hombre que la poseía la salvaguardia de Roma en medio del mundo bárbaro y pagano; el nombre de romano revestía de la invulnerabilidad y dignidad al ciudadano, librándolo de las penas infamantes. San Pablo para libertarse de ser azotado dijo: Soy romano y como romano fue respetado. Era así como Roma correspondía a la idea del poeta latino, relativa a su misión en la humanidad: Parcere subjectis et debellare superbos. $\mathrm{Y}$ así es como vemos aparecer a los Estados Unidos, proclamando la invulnerabilidad de de todo el que ha querido ser americano, y en medio de la barbarie moderna de la Europa (p. 231-232).

El anticlericalismo combatiente de Bilbao se manifiesta con virulencia en el ensayo titulado "Chile, la cuestión religiosa con motivo de un edicto del Arzobispo de diciembre de 1853", acerca de los males y errores del catolicismo en general y del jesuitismo en particular ${ }^{52}$. Recurre al latín para marcar la impronta dogmática del catolicismo, citando de nuevo la Ley de las XII Tablas ("Adversus hostem, aeterna autoritas esto»), de la que dimanaría la doctrina de Ignacio de Loyola, comparado con la serpiente del Paraíso y con un Coloso que «arrancará la libertad del pedestal divino del infinito para poner en su lugar un cadáver (per inde ac cadaver)", apoyándose en el voto de

50. Para esta batalla del 490 a. C, véase el relato de Heródoto VI, 102-114.

51. En Hechos 22, 25-29 San Pablo apela a su ciudadanía antes de ser conducido antes al Sanedrín. En cuanto a la cita latina, se trata de un verso de la Eneida (6, 853), donde Anquises vaticina la misión de Roma, que se convirtió en proverbial: véanse, por ejemplo, dos pasajes del Quijote (I, 52; II, 18,165) y otro de Fray Antonio de Guevara (Libro Aúreo de Marco Aurelio, 1528).

52. En su crítica a los jesuitas (p. 234-276) debieron de pesar los argumentos de Quinet y Michelet, quienes les habían dedicado una monografía (Les Jésuites, 1838). 
obediencia ( $u t$ senis baculus») ${ }^{53}$ y con el pretexto de glorificar a Dios ( $A d$ maiorem Dei gloriam») ${ }^{54}$.

En «Necesidad de una nación» establece los tres principios que, según él, conforman el genio de cada pueblo: organización e instinto, clima y territorio, y religión, denominados respectivamente elemento interno, externo y ontológico. El predominio de cada uno de estos elementos explicaría las peculiaridades de las distintas razas. Así lo aplica:

Hay otra raza en que predomina el elemento social, la unidad, el corazón, la ciudad; que tiene por móviles el culto de lo bello y el entusiasmo. Dadle por campo los climas esplendentes de la Grecia y de la Italia, las minas de Paros y Carrara y veréis los portentos del arte; ¡cuál será su legislación? El elemento autoritario, la unidad hasta el despotismo. Tales son los códigos romanos, la propiedad y la familia en Roma, y el Papado después, ¿̨cuál será su religión? El socialismo de los frailes y la inhabilidad entronizados (p. 282).

Y entre los pueblos de raigambre grecolatina, Francia representa la mixtura afortunada de «la lógica de Roma, las magnificencias de la Grecia, el encanto del genio de los Galos. Cuando era clan, tribu, escaló el Capitolio; cuando la feudalidad tomó a Jerusalem, cuando monarquía se llamó Luis XIV, cuando era imperio deslumbró a la tierra (p. 283)» ${ }^{55}$.

Ahora bien, la premisa de cualquier nación reside en la libertad, esa libertad que aún no se ha encarnado plenamente en la Historia, pero que alcanzó a brillar esplendorosa entre los griegos:

La antigüedad reconoció, practicó en algunos pueblos de la Grecia la unidad o soberanía del ciudadano. El ateniense era soldado, remaba en las galeras, asistía al foro, discutía, votaba, gobernaba en todo ramo. En la plaza escuchaba a Demóstenes, en las escuelas a Aristóteles, en los teatros a Sófocles. Era el ciudadano en todo el esplendor de su tiempo (p. 285-286).

En este contexto Bilbao aborda uno de los temas centrales de su pensamiento político, la necesidad urgente de la unidad hispanoamericana para resistir el empuje de los Estados Unidos, nación que admira, pero en la

53. Remitimos, sucesivamente, a las páginas 241; 249; 253. Véanse Constituciones de la Compañia de Jesús, 547.

54. Latinismo citado por partida doble (p. 253 y p. 261).

55. El asedio del Capitolio en el 390 a. C. es descrito por Livio (5, 47 ss.). 
que empieza a percibir los rasgos del Imperio: «Roma avanzaba con la fuerza de la unidad devorando en detalle a las naciones. Reía la Grecia, cuando Cartago sucumbía -después el Asia despreciaba ese poder cuando la Grecia era convertida en provincia romana, y el Asia con su orgullo, su ociosidad, su número, sus regiones y riquezas vino a desfilar bajo los arcos de triunfo de los cónsules (p. 288-289)». Así pues, el pasado enseña que la victoria del Norte será inevitable mientras continúe «la anarquía estúpida» en el Sur. La confederación americana que propuso Bolívar, sería insuficiente, pues: «La lucha no es de número, es de ideas. Elevemos la idea; y tendremos el palladium de la victoria (p. 289)»" ${ }^{56}$.

Nuestro autor cierra esta recopilación de ensayos con "Los Soliloquios del proscrito», dedicado a su maestro Edgar Quinet, "hoy proscrito». Comienza con una cita literal de Virgilio: "Et dulces moriens reminiscitur Argos (p. 291)» ${ }^{57}$; y prosigue recordando su viaje por Europa, desterrado de su patria por amar la libertad. El tono elegiaco del pasaje se intensifica con las frecuentes evocaciones de la cultura clásica:

He sentido en Roma el recuerdo de esa patria anterior que cobijamos en los delirios del orgullo, pero sobre sus ruinas he escuchado la voz permanente del castigo. Alpes y Apeninos, sobre cuyas crestas hemos encontrado las huellas de César y de Napoleón, yo cargaba vuestros recuerdos colosales para trasportarlos a los Andes[...] Peregrino del porvenir, he buscado la Jerusalem sin fariseos, la Roma sin patricios, la Francia sin doctrinarios, la humanidad sin jesuitas. Como el viajero de la Antigüedad, me he sentado en el hogar de toda clase de hombres, para escuchar nuestra historia, para recoger los fragmentos dispersos del corazón del hombre (p. 292294).

\section{Roma y el imperialismo: El Congreso Americano}

Durante su estancia en Lima, y a pesar de su condición de asilado, Bilbao no se mantuvo al margen de la política peruana, sino que sus críticas al nuevo régimen y sus ataques al clero provocaron su expulsión del país. El 24 de mayo de 1855 partió de nuevo hacia Europa ${ }^{58}$. Acuña entonces la

56. La leyenda sobre la estatua de Palas Atenea, garante de la integridad de la ciudad que la poseyera, se integra en los orígenes de Roma desde Virgilio (Eneida 2, 162 ss.)

57. Eneida 10, 782: «Y al morir se acuerda de la dulce Argos».

58. Para los hitos biográficos de este periodo, véanse Witker (op. cit., p. 314-315) y López 
expresión "nuestra América», para designar la unidad latinoamericana, y la intenta dotar de contenido programático en "El Congreso Americano» 59.

Según Bilbao la Independencia del Continente americano constituye «el espectáculo más trascendente de la Historia» ${ }^{60}$. Ciertamente, en el pasado:

La Grecia, con su filosofía, su arte y su política, fijó en el firmamento de la historia el astro más esplendente de la inteligencia y el más fecundo del heroísmo. Roma, con su espada, fue el arado terrible que abrió el surco sepulcral de una ciudad universal. Y los bárbaros vencedores del Imperio, aparecieron como imagen de pueblos convertidos en elementos que pasan como la tempestad sobre los monumentos pasados (p. 273).

En cambio, América representaría el porvenir, la tierra hospitalaria de los náufragos de esa Europa que ha abjurado de la Razón. No obstante, se enfrenta a un grave peligro, el imperialismo encarnado, por una parte, en el paneslavismo de Rusia y, por otra, en la política expansionista norteamericana que se ha adueñado de parte de México y California, y amenaza a Panamá ${ }^{61}$. América latina se encuentra en desventaja ante el Norte: «Los Estados Des-Unidos de la América del Sur, empiezan a divisar el humo del campamento de los Estados Unidos [...] Ese coloso juvenil que cree en su imperio, como Roma creyó en el suyo (p. 277)». Y continúa:

Despreciando tradiciones y sistemas, y creando un espíritu devorador del tiempo y el espacio, han llegado a formar una nación, un genio particular. Volviendo sobre sí mismos y contemplándose tan grandes, han caído en la tentación de los Titanes, creyéndose ser los árbitros de la Tierra y aun los contenedores del Olimpo (p. 278).

Ante tal reto, los sudamericanos deben aprender las lecciones de la Historia:

\footnotetext{
Muñoz (op. cit., p. 59-61).

59. Citamos por la edición de A. Witker (op. cit., p. 273-289), donde lleva el título de «El Congreso Normal Americano». Sin embargo, preferimos el dado por el mismo autor (El Congreso Americano), quien lo leyó en París el 22 de junio de 1856 ante un grupo de exiliados sudamericanos: véase R. López Muñoz, op. cit., p. 61.

60. Véase Lastarria (op. cit., p. 67): «esa revolución de 1810, el acontecimiento más grande de los siglos después del cristianismo».

61. En la página 275 la califica de «futura Constantinopla».
} 
Cuando los romanos quisieron formar una marina, tomaron por modelo a un buque cartaginés; cambiaron su espada por la española, se apoderaron de la ciencia, la filosofía y el arte de los griegos sin abdicar de su genio, y abrieron un templo a las divinidades de los pueblos mismos a quienes combatían, como para asimilarse al genio de las razas y la fuerza de todas las ideas. Del mismo modo nosotros debemos apoderarnos del hacha del yanqui para desmontar la tierra; debemos enfrenar la anarquía con la libertad, único Hércules capaz de dominar esa hidra; derribar el despotismo con la libertad, único Bruto capaz de extinguir a todos los tiranos (p. 279) ${ }^{62}$.

Rememorando el proceso de la Independencia americana, Bilbao encuentra en los antiguos un contrapunto para «los Libertadores»: "Albión retrocedió ante los héroes de Plutarco que os constituyeron en federación más grande (p. 280)». Mas el tiempo apremia, y para ilustrarlo acude al anecdotario romano: "Así como Catón, el censor, terminaba todos sus discursos con una frase destructora, delenda est Cartago, y así al fin de todos los raciocinios, uno es el pensamiento creado que se presenta: la necesidad de la Unión Americana (p. 281)» ${ }^{63}$.

Aunque la historia de Roma ilustra a la perfección tanto los peligros del imperialismo como los medios necesarios para combatirlo, al chileno le resulta aún más paradigmático el caso griego:

¿Quién ha brillado más en la historia que la Grecia? Poseedora en alto grado de todos los elementos y condiciones que pueden presentar al hombre en la plenitud de sus facultades asociadas y en el goce completo de la personalidad, sucumbe por la división y la división apaga la luz que su heroísmo conquistara. Nosotros nacemos, y al nacer, en la cuna nos asaltan las serpientes. Tenemos, como Hércules, que ahogarlas, y esas serpientes son la anarquía, la división, las pequeńas naciones. El campo nos provoca para realizar los doce trabajos simbólicos del héroe. Los monstruos espían en la selva de nuestras preocupaciones, la hora y la prolongación del letargo. Las columnas de Hércules están hoy en Panamá. Y Panamá simboliza la frontera, la ciudadela, y el destino de

62. Sobre el asesinato de César por Bruto véase Suetonio, Iul. 82.

63. Este conocido aserto ha sido transmitido por Floro (Epit. 2, 15,4): «ceterum censeo, patres conscripti, Carthaginem esse delendam (por lo demás planteo, senadores, que Cartago debe ser destruida)». 
ambas Américas. Unidos, Panamá será el símbolo de nuestra fuerza, el centinela de nuestro porvenir. Des-Unidos, será el nudo gordiano cortado por el hacha del yanqui y que dará la posesión del imperio, el dominio del segundo foco de las elipsis, que describen la Rusia y los Estados Unidos en la geografía del globo (p. 282) ${ }^{64}$.

Bilbao argumenta que si Rusia es la «barbarie absolutista», los Estados Unidos significan la «barbarie demagógica», que «armoniza los elementos heterogéneos de su nacionalidad para alcanzar la posesión de su Olimpo, que es el dominio absoluto de la América (p. 285)». Y puesto que el expansionismo del Norte afectaría a todo el continente, propone la convocatoria de un «Congreso Americano» para discutir y votar un documento de medidas urgentes.

En el «Epílogo» (p. 287-288), Bilbao llama de nuevo a traspasar las fronteras de ese Viejo Mundo al igual que su admirado Colón, que «se apoderó de todas las tradiciones, leyendas y poesías de la Antigüedad que indicaban un mundo perdido u olvidado para fecundizar su inspiración y sus cálculos científicos». Siguiendo las huellas de Hércules y Alejandro Magno, el Almirante inauguró una nueva era de la humanidad cuando descubrió un paraíso de la paz y la libertad, el Nuevo Mundo de los emigrantes y los proscritos, para que: «Sepamos contemplar a la humanidad doliente, que cual otro Prometeo protesta encadenado en Asia, África y Europa, dormitando bajo el peso de la naturaleza sin libertad, o bajo la ciencia de la fuerza o el engaño, y que espera quizás la revelación de la justicia» ${ }^{65}$.

\section{Modelos clásicos de filosofía y política: La América en peligro}

En abril de 1857 regresó a América y se instaló en Buenos Aires. Casi de inmediato funda la efímera Revista del Nuevo Mundo y se incorpora al periódico El Orden, desde cuyas páginas intervendrá en los debates políticos argentinos, especialmente en las cuestiones religiosas ${ }^{66}$. También organizó un

64. La leyenda del nudo de Gordio aparece en la Vida de Alejandro de Plutarco (2-4).

65. La tradición del Prometeo benefactor de la humanidad reposa en la tragedia de Esquilo. En el siglo XIX el Titán rebelde se convierte en uno de los prototipos del héroe romántico, como ilustran el poema de Byron (1816) y sus secuelas en Prometheus Unbound (1818) y en Frankestein: the Modern Prometheus de Percy y Mary Shelley, respectivamente. Edgar Quinet, por su parte, escribió el drama Prométhée (1838), que debía de conocer Bilbao.

66. Para esta etapa remitimos a la "Introducción» de Witker (op. cit., p. xxii-xxiii) y a 
Club literario, que inauguró en noviembre de 1858 con la conferencia «La ley de la Historia». En este discurso, retomando las ideas de Bolívar acerca de la necesidad de revisar la historia americana desde una óptica nueva, Bilbao proclama su identificación con los oprimidos de todo tiempo y lugar:

Y diremos a los primeros [los opresores]: fui paria, fui de la casta servicial en la India, esclavo en Grecia y en Roma, siervo en la edad media. Tuve sed de justicia y no me disteis de beber; tuve hambre de lo divino y humillasteis mi razón divina $[\ldots]$ He vivido y vivo en proletariado inmenso, siervo del capital y de la usura, esclavo de los dogmas [...] Habéis usurpado y usurpáis mi soberanía en todo el mundo, con la fuerza y la mentira, usurpando mi derecho al gobierno con monarquías y caudillos, con sacerdotes y con falsos profetas. Atrás vosotros, que la ley de la historia es ser libre en todo tiempo y lugar, en alma y cuerpo ${ }^{67}$.

El 6 de agosto de 1862 se termina de imprimir una de sus obras fundamentales, La América en peligro, como respuesta a la invasión francesa de México ${ }^{68}$. En la primera parte, analiza cómo el imperialismo de Napoleón III probaría que los franceses no han aprendido de sus derrotas: «Mas todo pasa y la Francia olvida; es humo esa gloria, es necesario renovar esa gloria de humo, y el Minotauro pide víctimas para abastecer la ración de cadáveres que la Francia sacrifica en la pira de su vanidad y orgullo (p. 12)». Frente a esta nación degradada, que ha abjurado de sus ideales revolucionarios, el chileno opone «el prodigio de América»:

Y es digno de notarse este fenómeno, no apercibido por los escritores y pensadores de América: de cómo la IDEA sólo de República, ha ido engendrando una sociedad republicana. Es el caso de lo que autores de epopeya llaman, la intervención de lo maravilloso. Dicen que la epopeya moderna carece de ese elemento, pero he aquí que la epopeya americana, puede presentar la deliberación de sus destinos en otro Olimpo que el de Homero, en otro cielo que el del Tasso, en el firmamento de

R. López Muñoz (op. cit., p. 61 ss.)

67. Citado por E. Fernández Nadal, «Memoria, identidad, poder. Francisco Bilbao y las filosofías de la historia de los vencedores», Polis: Revista On-Line de la Universidad Bolivariana, Volumen 4, Número 12, 2005.

68. Citamos por la primera edición: F. Bilbao, La América en peligro, Buenos Aires: Imprenta Bernheim y Bouco, 1862 [digitalizada en Memoria chilena. Portal de la cultura de Chile: www.memoriachilena.cl.]. Está dedicada a Quinet y Michelet. 
Platón, en la mente del Ser Supremo que produce la Minerva de la libertad. Una IDEA, sin escuela, sin enseñanza, sin un cuerpo de profesores, de sacerdotes o de apóstoles [...] he aquí el milagro, americanos, que ninguno de vuestros sabios os señala. He aquí el elemento maravilloso de la epopeya del nuevo continente (p. 18) ${ }^{69}$.

Por una paradoja del destino, el peligro para la idea republicana venía de Francia, cuna de la Revolución, donde el pueblo, hastiado de demagogos y de comunistas utópicos:

sólo pide paz y riqueza, que viene a ser el panem et circenses, de los romanos de la decadencia [...] Y esos pueblos que piden pan y juegos, necesitan que sus gobiernos mantengan el circo repleto de gladiadores, de fieras y de productos de todos los climas. De aquí la necesidad de expedicionar Asia, África y América (p. 20-22) ${ }^{70}$.

Por lo tanto, bajo el pretexto de colonizary «el charlatanismo del progreso» se esconde una voracidad imperialistaque recuerdalade Roma: «Yen bocadeellos, en efecto, siempre triunfa la justicia, porque para ellos la justicia ES ELÉXITO. Triunfa Roma, es la civilización quien triunfa. Triunfan los bárbaros contra Roma, cae el mundo en la barbarie, nace la feudalidad, se hace la noche en la historia: Es la civilización que se renueva (p. 26)».

América, sin embargo, debía enfrentarse a otro enemigo aún más poderoso y oscuro que dimanaba de su interior. Este peligro interno se explica a partir de factores materiales, en especial su población escasa y dispersa ${ }^{71}$, y por «errores intelectuales» de tipo filosófico, religioso, político, moral, científico, económico y administrativo. Como fundamento de su argumentación Bilbao invoca a una autoridad griega:

Si nos atenemos a la filosofía de Platón, podemos decir: la causa del error es el olvido. Al afirmar por la ilusión de los sentidos, o por la apariencia sensible, que el sol es el que gira, olvidamos que no puede recorrer esa distancia en

69. Como modelo de esta epopeya americana de la libertad Bilbao pensaba en La Araucana: «Para Chile es la Ilíada [...] Si Chile debe ser una nacionalidad, o algo sui generis, ha de apoyarse en Ercilla», escribe en la carta a los hermanos Amunátegui fechada en Buenos Aires el 16 de enero de 1862 y citada por Witker (p. xxvii).

70. Esta conocida expresión deriva de Juvenal (Sat. 10, 81).

71. Al respecto comenta: Desde Méjico a Chile: «adparent rari nautes» (p. 30), primer hemistiquio de Eneida, 1, 118. 
24 horas. Pero olvido supone conocimiento anterior. Así es. Según Platón, poseemos los conocimientos en germen, y la enseñanza es tan sólo desarrollo, trabajo de partera para hacer alumbrar la humanidad. Pero haciendo abstracción de la opinión de Platón, sostenemos que el olvido de algún elemento necesario que entra en la concepción de la verdad, es la causa de casi todos nuestros errores (p. 33) 72 .

Consecuentemente, América debe «recordar» su destino y, como en ensayos anteriores, nuestro autor aduce el ejemplo griego: «Bajo el aspecto de la inteligencia solamente, el hombre o pueblo más fuerte es el que vive con mayor verdad y con menor error. Grecia, la más pequeña nación de la Antigüedad, por sólo poseer y practicar el principio de la personalidad, y de la República, fue más fuerte y fecunda que todo el Oriente, con sus imperios colosales (p. 34)».

Pasa a abordar el problema religioso, tomando como lema el siguiente aserto de Lamennais: «Libertad y catolicismo, son dos palabras que radicalmente se excluyen». En consecuencia, aunque Bilbao dice respetar a los católicos sinceros, no puede admitir la "capitis-diminutio» $^{73}$, la decapitación de la libertad de pensamiento que imponen los dogmas de la Iglesia. Por otra parte, el reparto de poderes entre la Iglesia y el Estado le parece sólo el disfraz de un pensamiento egoísta y cínico, en el que «la bolsa se trasforma en templo y foro. La bolsa se convierte en el Capitolio de los pueblos pervertidos [...] ¡El ciudadano se aísla, se separa, abandona los comicios y se entrega a la fatalidad o se somete a pasar las horcas caudinas de la compañía de comercio vencedora! (p. 45)» ${ }^{74}$. Tal distinción entre lo temporal y lo espiritual, según Bilbao, responde a un sofisma jesuítico: «División leonina por cierto. Pobre cuerpo, pobre César, pobre temporal, imbécil sociedad, si tragas la gran concesión que te hace la infalible Iglesia [...] Es como si una aristocracia poderosa, concediese al pueblo el derecho de nombrar sus tribunos, sus diputados, y se reservase el derecho de imponer la contribución (p. 48)». Algo semejante ocurría en Roma:

72. Sobre la comparación «socrática» entre el quehacer del filósofo y el de la partera («mayeútica»), véase Platón, Teeteo 149a-151.

73. Véase p. 35-36. La también denominada capitis minutio de acuerdo con el derecho romano significa la pérdida de derechos civiles total o parcial: cf. Gayo, 1.1; D., de capite minutis, 4. 5 .

74. El episodio de las «horcas caudinas» durante la guerra entre romanos y samnitas (Livio $11,4,3)$ originó la expresión formularia para la derrota humillante. 
El pueblo conquistaba sus derechos uno por uno, elegía sus magistrados, votaba la ley, juzgaba en el foro, velaba en el senado, pero jamás la aristocracia le concedió el derecho a la interpretación del trueno, del rayo, de las entrañas de las víctimas, de la voluntad divina, el derecho religioso sacerdotal, pontifical en una palabra. Con ese derecho, el patriciado suspendía cuando quería los comicios, declaraba la paz o la guerra, hacia intervenir la omnipotente y aterrante voluntad de Júpiter tonante, para resolver una duda, contrariar, burlar, anular la voluntad del pueblo. Era lo espiritual sobre lo temporal, era la Iglesia sobre el Estado, el pontífice sobre el pueblo...Pero había más unidad, más verdad, más penetración de los elementos humanos, que el catolicismo separa. Senatus populusque Romanus era la fórmula verdadera, pues, decía que la ley emanaba de las dos autoridades para tener toda la fuerza moral. No así entre nosotros. La Iglesia habla sola. El Estado habla solo. Dualismo, lucha, y despotismo y anarquía como consecuencia (p. 48-49).

Después de denunciar los «sofismas» de los jesuitas y «la intolerancia» de Mahoma ${ }^{75}$, se niega a aceptar cualquier forma de dogmatismo religioso, entre otras cuestiones porque Concilios que se decían infalibles, desautorizaban a otros también declarados infalibles. Así, el Concilio de Nicea, donde la violencia de Constantino impuso el dogma de la divinidad de Cristo, por sufragio, trescientos años después de muerto Jesucristo y en una reunión «anárquica» de poco más de trescientos individuos ${ }^{76}$. Y se pregunta: «¿Esa autoridad es infalible, y discute, vacila, titubea, acepta neologismos como el homoousion (consubstancial), busca en la teoría de Platón la explicación del verbo, y el resultado de esa discusión, de ese estudio, de esas transacciones entre doctrinas, se me impone después como solución infalible al problema, y como revelación divina? (p. 55)» Respecto a la creencia en la revelación, plantea que si Dios habla: «¿Cómo habla Dios a los hombres? ¿En Hebreo o Griego, con labios y garganta?» Pero, si Dios no habla, sino que ilumina,

75. Bilbao suele asociar jesuitismo con «sofisma» y «cinismo». En cuanto a su crítica a la doctrina de Mahoma, recuerda el título de una pieza teatral de Voltaire publicada en 1742 ( $L e$ fanatisme, ou Mahomet le prophète).

76. Véanse p. 55-56. El Concilio de Nicea, donde se condenó el arrianismo como herejía y se estableció el dogma de la divinidad de Cristo, se desarrolló en efecto en una única jornada el 20 de mayo de 325. Homoousion es el término adoptado por Atanasio a partir del neoplatonismo: cf. De dec. Syn. Nic. 25, 26. El conocimiento de Bilbao de la historia de Bizancio podría deberse a los cursos de historia del cristianismo que siguió en el Collège de France. 
concluye: «esa iluminación es siempre la razón iluminada, es cuestión de más o menos alcance, pero no de negación de la razón. Platón y Newton son reveladores verdaderos y no farsantes como Moisés y Mahoma. Y los grandes reveladores son los grandes razonadores que racionalizan la humanidad (p. 57)» ${ }^{77}$.

Bilbao postula la necesidad de predicar una nueva religión, que no necesita de nuevos «reveladores y utopistas» que anuncien el nacimiento de un Mesías, «de un sucesor de Zeus, de Júpiter, o de Jehová (p. 62)». Esta religión de la Ley, sin embargo, no provocará la anarquía como anuncian sus adversarios, puesto que al fin y al cabo, señala con ironía: «no hay masas más desenfrenadas que las masas católicas [...] ¿Y quién desencadenaba a las masas como Eolo a los vientos, cuando era necesario degollar a los protestantes y exterminar a los herejes? (p. 66)». Si el freno de los católicos es el terror provocado por los castigos del Infierno, su único consuelo reside en la esperanza de la resurrección, es decir, en una idea en absoluto original:

Y no sois vosotros, los hijos de la raza de Abraham, los que podéis vanagloriaros de haber legado a la humanidad el dogma de la inmortalidad del alma. Fue uno de los nuestros, no el que primero la afirmó, sino el que hizo la más bella demostración de esa doctrina. Fue Platón, como trescientos y más años antes de Jesucristo, quien iluminó al mundo con la revelación más bella de la más bella de las razas. Somos pues los racionalistas los primeros que hemos procurado demostrar para convencer: el dogma de la inmortalidad del alma. Esa gloria es nuestra y no vuestra. El gran consuelo ha sido demostrado por Platón. Y para resumir: vuestro consuelo se llama gracia, misericordia, indulgencias, ceremonias exteriores, prácticas externas, absolución del hombre. Nuestro consuelo se llama JUSTICIA ¡Comparad y juzgad! (p. 79).

En la relación de los adelantados y mártires de esa nueva religión sustento de la salvación de América, Bilbao menciona a dos sabios griegos:

77. Siguiendo a Michelet, afirma que, para resolver esta contradicción doctrinal, Ignacio de Loyola habría enunciado el principio de obediencia ciega, que ofrece en latín: «Visum est nobis in Domino nullas constitutiones posse obligationem ad peccatum mortale vel veniale inducere, nisi superior (in nomini J. C. vel in virtute obedientae) juberet (p. 58)»; es decir, «pensamos en el Señor que ningunas Constituciones puedan obligar a pecado mortal o inducir a venial, si no lo mandare el Superior (en el nombre de J. C. o en virtud de obediencia)»: cf. Constituciones de la Compañia de Jesús, 602. 
El pensamiento del hombre en la verdad es como la palanca de Arquímedes: Dadle un punto de apoyo y hará saltar al mundo de su órbita ${ }^{78}$. Más espanto causaba a los romanos un gesto de Arquímedes, que las fuerzas todas de la gran ciudad de Siracusa. ¿Por qué? porque poseía la verdad científica [...] Son vulgares los ejemplos tantas veces presentados de Sócrates, Jesucristo y Galileo. Sócrates muere por enseñar la unidad de Dios y el idealismo. Jesucristo muere por enseñar la pureza, la caridad [...] Y no se crea que pretendo lisonjear; Jesucristo es sublime como hombre, y como Dios absurdo. Y esos individuos han triunfado. Sócrates venció al paganismo, Jesucristo a la Sinagoga, Galileo a la Iglesia católica (p. 106-107) $)^{79}$.

Ahora bien, la luz de estos precursores fue oscurecida por «el paganismo católico», supersticioso y milagrero, de ahí la necesidad de nuevos profetas de la Razón, como Lutero, Voltaire y Lamennais. Bilbao retorna al tiempo presente para advertir: «Y sobre todo no olvide el hombre, que bajo el imperio de Nerón, o bajo la dictadura de Rosas, que en medio del circo antiguo, o en medio de las llamas de los autos de fe de los católicos, DEBE DAR el testimonio de la verdad (p. 109)». Y reprocha: “¿Qué hacemos para aplicar al Viejo Mundo, la palanca de Arquímedes? [...] Muy poco, hermanos míos (p. 111)». A continuación, denuncia la incoherencia de individuos, organizaciones y gobiernos pretendidamente «racionalistas», que traicionan sus ideales y pactan con la Iglesia, participan en sus cultos y ritos, y sufragan sus gastos ${ }^{80}$. El racionalista, por el contrario, debe afirmarse en su verdad, aunque combata en solitario contra el mundo. Es un mártir de la libertad a quien no doblegan ni una legión de enemigos, ni tampoco las mujeres: «El racionalismo pertenece al sexo fuerte. Las mujeres serán lo que los hombres quieran. La República romana nos daba Cornelias, y el imperio romano Mesalinas. Alejandro VI Papa, nos dejó a Lucrecia Borgia, y la República francesa a madame Roland (p. 115)» ${ }^{81}$.

78. Arquímedes murió en el 212 a. C. durante la toma de Siracusa por los romanos: Plutarco, Marcelo 14. Su célebre petición a Hierón ha sido trasmitida por Papo, Collect. 8, 11.

79. La comparación entre Sócrates y Cristo se convierte en tópica desde la Antigüedad tardía: Justino, Apología I, 5; 46.

80. En su argumentación intercala latinismos (p. 113): «No necesita la libertad, el Te-Deum de una Iglesia que ayer decía: Deus salvum fac regem; -y al otro día: Deus salvam fac rempublicam; y al día siguiente: Deus salvum fac imperatorem».

81. La mención de Mme Roland, historiadora y revolucionaria girondina guillotinada en 1793, se explica por la afinidad con la Gironda de Bilbao y otros liberales, incluido Lastarria, 
La América en peligro se cierra apelando a la creación de una Confederación Americana, basada en la Razón, la Libertad y la Justicia, y con la propuesta de un programa político de medidas urgentes para evitar controversias estériles: «Los bizantinos disputaban encarnizadamente sobre los panes-azimos, cuando ya Mahoma II golpeaba las puertas de Constantinopla (p. 131)» ${ }^{82}$.

\section{El ideal griego y la decadencia de Roma: El Evangelio Americano}

La última obra de Francisco Bilbao aparece en septiembre de 1864 pocos meses antes de su muerte, cuando se encontraba gravemente enfermo y decepcionado por el discurrir de la política argentina ${ }^{83}$. Bilbao quiere legar a las jóvenes generaciones lo que denomina «Biblia americana» o "Corán americano», es decir, una exposición de los verdaderos principios en los que deberían asentarse el ser y el destino de América latina. Este «testamento político» está redactado en un tono visionario, como si se tratase de una revelación profética, de ahí la apropiada elección del título. Su carácter eminentemente recopilatorio se manifiesta tanto en las frecuentes remisiones a obras anteriores a propósito de los tópicos de su pensamiento, cuanto por la repetición de citas clásicas ya aludidas en otros contextos.

En la primera parte del ensayo la historia reciente se explica acudiendo al símbolo religioso de la ascensión y caída de la Razón, hasta concluir en un estado de injusticia que afecta especialmente a los trabajadores:

a pesar de su pobreza, ese pobre, ese gaucho, guaso, roto, plebeyo, peón, mano de obra, artesano del día, ese hombre en fin, es el que soporta el edificio social sobre sus hombros, como en los templos y otros edificios antiguos las cariátides [...] He ahí el punto estratégico de la gran política regeneradora de la América. La cariátide será estatua, la estatua será hombre (p. 35).

que en la Sociedad de la Igualdad habían adoptado como alias políticos los nombres de sus líderes: véase E. Delano, op. cit., p. xxii.

82. Se refiere a la polémica sobre la «especie» de la comunión que produjo el Cisma entre la Iglesia oriental y la occidental en 1053. Sin embargo, la toma de Constantinopla por Mehmet II ocurrió en 1453.

83. Para esta etapa véase López Muñoz, op. cit., p. 68 ss. Bilbao falleció el 19 de febrero de 1865. Citamos por la primera edición: F. Bilbao, El Evangelio Americano, Buenos Aires: Imprenta de la Sociedad Tipográfica Bonaerense, 1864 [digitalizada en Memoria chilena. Portal de la cultura de Chile: www.memoriachilena.cl.]. 
Para cumplir esta tarea redentora, Bilbao, como un nuevo Virgilio, invita al lector a seguirlo «en la peregrinación a través de los círculos que forman el infierno de la España» ${ }^{84}$.

El análisis crítico de la historia de España se desarrolla ampliamente en la segunda parte, que está encabezada por uno de sus aforismos latinos preferidos: "Adversus hostem, aeterna auctoritas. Garantía eterna contra el enemigo (p. 36)». Bilbao destaca los dos hechos del pasado hispano que más habrían repercutido en la abolición de la libertad y la identificación entre patriotismo y religión en el Nuevo Continente: por una parte, la llegada de los visigodos tras la caída del Imperio romano y la consiguiente lucha contra el arrianismo, y en segundo lugar, la invasión musulmana y la Reconquista. Así forjados, los españoles llegaron a América, a ese "Jardín del Edén» poblado por hombres inocentes y hospitalarios, y la historia del encuentro de ambas razas es la crónica del horror:

No presenta la historia de la humanidad, aun saliendo de la barbarie, un sistema de barbarie más sostenido que el de la conquista de América, y esto sólo dista cuatrocientos años de nosotros. Los romanos conquistaron, ¡pero qué diferencia! El país conquistado convertido en provincia romana, era respetado en sus creencias, aceptada su población, poblados los lugares incultos o desiertos: no exterminaban. Los griegos eran civilizadores y fueron los menos conquistadores. Honor eterno a esa raza, la más grande lumbrera de la humanidad. El pueblo revelador por excelencia, el pueblo de la Filosofía y de la democracia (p. 68).

Y de nuevo, como colofón de las matanzas de indígenas que marcaron las etapas de la primera expedición, repite esa sentencia romana, en su opinión, estandarte del catolicismo hispano: «Adversus hostem, aeterna auctoritas esto (p. 69)». Sobre este paisaje de destrucción y muerte, los españoles levantaron el edificio del despotismo e instauraron las instituciones de la conquista, entre ellas una educación:

limitada sólo a la teología, la jurisprudencia y el latín. Ignorancia de las ciencias físicas. En filosofía, una miserable escolástica, que se servía del silogismo de Aristóteles para procurar dar una apariencia de raciocinio al dogma supremo

84. Página 35. La sombra de Dante sobre Bilbao se acrecienta al final de su vida. Así, la "Cronología» de L. Benavides en la edición de Witker (p. 315) registra en el año 1857: "publica su obra La Tragedia Divina, pieza de corte griego y de espíritu filosófico heroico». No parece casual esta inversión antinómica del título de la Divina Comedia. 
y soberano, que era indiscutible. Se educaban charlatanes ergotistas, que bien caro cuestan a la América hasta hoy día (p. 80).

Dado que de la herencia española no se puede salvar nada, Bilbao, como otros intelectuales de su tiempo, propugna la urgente necesidad de «desespañolizar» América ${ }^{85}$.

La tercera parte del ensayo ostenta el título de "Revolución» ${ }^{86}$, término que Bilbao define como la lucha contra el Mal, una lucha cuyo resultado postrero está por escribir, de ahí que critique la concepción fatalista de la Historia, al modo de Bossuet para quien:

todos los acontecimientos anteriores a la era cristiana se encadenan de una manera fatal para preparar el cristianismo. Si antes conocíamos la historia de Sesostris, de Cyro, de Alejandro, de César como la de grandes conquistadores o malvados, según la doctrina histórica, esos personajes, esos imperios con todas sus ruinas, grandezas y desastres, conspiraban fatalmente al nacimiento de Jesús de Nazareth (p. 92)».

Pero esta doctrina falaz no conviene al Nuevo Mundo, que debe repetir el lema de Lucano: "CAUSA VICTRIX DIIS PLACUIT, SED VICTA CATONI. La causa vencedora agradó a los Dioses (el éxito, o la fortuna), mas la vencida a Catón (p. 94)».

Por otra parte, aunque las naciones hispanoamericanas hayan conocido etapas de buen gobierno ${ }^{87}$, en general no resisten la comparación con los vecinos del Norte:

85. En una nota de la página 88 se hace eco de la respuesta de E. Castelar en la Democracia de Madrid contra su artículo "Desespañolización».

86. Está encabezada con un fragmento de Lord Byron, que ofrece en versión bilingüe (p. 91). En concreto, el pasaje del poema Age of Bronze (1822) donde el heroísmo de los independentistas andinos y de los griegos levantados contra los turcos se compara con la acción de Harmodio, el célebre tiranicida ateniense (Heródoto V, 155 ss.; Tucídides, VI, 53 ss.). Bilbao anota: «Una causa común hace que sientan del mismo modo, millares de hombres, sean esclavos del oriente o ilotas del occidente».

87. «La justicia no era una palabra; se reconocía la ley: suum cuique tribuere. A cada uno lo suyo (p. 108)». Se trata de la definición de justicia según el derecho romano (Ulpiano, 1, 10.; D., de iustitia et iure, I.1.3): «Ius preacepta haec sunt: honeste vivere, alterum non laedere, suum cuique tribuere (Estos son los preceptos del derecho: vivir honradamente, no ofender a otro, dar a cada uno lo suyo)». 
Esos puritanos, o sus hijos, han presentado al mundo la más bella de las constituciones, dirigiendo los destinos del más grande, del más rico, del más sabio y del más libre de los pueblos. Es hoy en la historia esa nación, lo que fue la Grecia, el luminar del mundo, la palabra de los tiempos, la revelación más positiva de la divinidad, en la filosofía, en el arte, en la política. Esa nación ha dado esta palabra: Self-government, como los griegos la autonomía; y lo que es mejor, practican lo que dicen, realizan lo que piensan, y crean lo necesario para el perfeccionamiento moral y material de la especie humana [...] Es la nación poseída del demos, del demonio del perfeccionamiento en todo ramo. Es la nación creadora, y lo es, porque la soberanía es omnipresente en el individuo, en la asociación, en el pueblo (p. 118-119).

La sección del ensayo subtitulada "El Spiritus intus y el sursum corda. Idea, fuego y fuerza de la Revolución. El almo día (p. 131)» ${ }^{88}$, se abre con una paráfrasis del primer verso de la Eneida: «Rempublicam, populusque cano, canto a la República y a los pueblos, diríamos si fuésemos poetas, al principiar este capítulo que contiene el derrumbe del poder de España»; y continúa citando a Virgilio: "...ruit alto a culmine Troja» ${ }^{89}[. .$.$] ¡Oh pensamiento libre! [...]$ tú eres la musa del historiador, axial como eres la verdadera providencia de la historia, y la visión de la ley por el filósofo». En las páginas siguientes, el chileno recurre de nuevo a la tradición grecolatina para glosar los tiempos heroicos de la Independencia y de la Revolución en la América del Sur. En efecto, la libertad encendió una pira para quemar el Viejo Mundo, y «de las llamas de esa pira salió el renacimiento del Fénix [...] La gloria cubrió con su manto a las jóvenes naciones; y todas como vestales inspiradas sobre la trípode de los despojos enemigos, alzaron sus brazos vencedores, entonando al grande espíritu, el himno de la regeneración del mundo (p. 140)» ${ }^{90}$. El proceso no careció de dificultades, de retrocesos, pues la reacción «como esa hija de Lot» (sic) volvía los ojos al pasado. Pero

la idea había iluminado; los americanos habían mordido el fruto de la ciencia [...] y entonces ya no hubo sino marchar a la victoria garantizada por la resolución de vencer o morir.

88. Spiritus intus alit, «el espíritu que anima el mundo» (Virgilio, Eneida 6, 726), deviene aforismo, al igual que la frase litúrgica citada («arriba los corazones»), que introduce la Eucaristía.

89. Eneida 2, 290.

90. Sobre el ave Fénix, véanse Heródoto II, 73; Ovidio, Metamorfosis 15, 392 ss. 
Esta es la epopeya americana que espera su Homero. Esta es la historia de la Independencia que espera su Herodoto. Estos son los hechos y elementos que bullen en la hornaza esperando el molde de un Fidias para la estatua de la libertad (p. 142).

Recordando escritos anteriores, Bilbao insiste en que para América el peligro inmediato procede de esa Europa adalid de una civilización injusta, sometida a gobiernos reaccionarios y a las doctrinas jesuíticas. "Ese es el enemigo externo: Adversus hostem, aeterna auctoritas (p. 151)» ${ }^{91}$. Pero resulta peor el «enemigo interno», el «resabio de España» encarnado en el despotismo intolerante, enemigo de la verdad y de la libertad. Las amenazas de ese «neocatolicismo", "el gran sofisma de los tiempos modernos», no carecen de correlatos en la Historia:

Ya durante la decadencia del imperio romano, un espectáculo semejante presenciamos. El sacerdocio pagano vio que la filosofía, el progreso de las luces, el contacto de todas las religiones de la tierra en su panteón, iban descorriendo los velos del misterio, y creyeron no en la fabulosa, sino en la verdadera guerra de 1 os titanes espíritus-libres que asaltaban en realidad el Olimpo envejecido ${ }^{92}$. Júpiter desaparecía con su brillantísimo cortejo, y antes de que desapareciese la fe de los creyentes que alimentaban el altar, hubo tentativas de explicación, de reforma, de transformar en mitos las que antes creían realidades existentes en el cielo. El Evehmerismo (doctrina de Evehmero) dijo que los Dioses eran grandes hombres, inventores, fundadores y legisladores de pueblos, que habían sido divinizados. Otros dijeron que los Dioses no eran sino las fuerzas de la naturaleza, o las causas segundas. Otros procuraron reformar las antiguas concepciones, revistiendo a los Dioses de todas las virtudes que el progreso de la moral exigía. Procuraron conciliar el espiritu nuevo con la forma caduca, de los dogmas, y consiguieron detener o estorbar el movimiento regenerador del estoicismo, del idealismo y del Evangelio de Jesús. Pero no hubo remedio. El paganismo fue arrasado por la alianza del gobierno con la Iglesia (p. 160 ${ }^{93}$.

91. Nueva mención de Lex XII tab. 6.3.

92. De acuerdo con una tendencia documentada desde la Antigüedad, Bilbao parece confundir el episodio de la "Titanomaquia», donde los rebeldes son los dioses olímpicos, y la "Gigantomaquia», el asalto del Olimpo por estos hijos de la Tierra.

93. La doctrina sobre el origen de la religión atribuida a Evémero, («evemerismo») se 
Frente al Antiguo Régimen que lucha por mantenerse en la era de la Razón y del gobierno de la República, Francisco Bilbao proclama el ideal del nuevo americano, "el hombre íntegro" que posee todas sus facultades, cuyo modelo encuentra en la antigua Grecia, y no en la Europa moderna donde los siervos son: «multitudes de rebaños humanos. La burguesía es el hombre-Mercurio. La nobleza, o aristocracia feudal, es el hombre-orgullo. Los sabios son pura inteligencia. La mayor parte de los letrados son retórica. Los monarcas y sus familias son la raza de la usurpación y del crimen (p. 170-171)».

Nuestro autor termina entonando un himno a la esperanza: «Nuestro destino es feliz, pero bajo la condición del heroísmo ¡Gracias al Ser Supremo! ${ }^{94}$ Sea la última palabra de mi libro, escrito en el dolor y con la conciencia del peligro, una palabra de alegría y de victoria (p. 173)».

\section{Recapitulación}

En nuestro recorrido por los ensayos de Francisco Bilbao Barquín hemos detectado una continua presencia de la Antigüedad, la cual, por otra parte, se intensifica a partir de su primer viaje a Europa. A veces el componente clásico se manifiesta a través de la fraseología y de alusiones circunstanciales mitológicas e históricas, pero generalmente desempeña un papel destacado en la exposición dialéctica de su pensamiento político. De hecho, para Bilbao la civilización grecorromana constituye un referente de excepción a la hora de ilustrar las causas de los problemas de América y de proponer soluciones.

En esta función paradigmática, Grecia se identifica con sus ideales, en cuanto sería la tierra donde por vez primera brilló la Razón, encarnada en la democracia y la filosofía. Respecto a Roma, la actitud de Bilbao fluctúa entre la admiración y el rechazo. En efecto, si bien alaba sus instituciones republicanas y la tolerancia y magnanimidad del Imperio, no por ello deja de resaltar los males derivados del ejercicio de un poder absoluto, de ahí su caracterización como precedente de las aspiraciones imperialistas contemporáneas en Europa y los Estados Unidos de Norteamérica. De acuerdo con lo anterior, los personajes griegos se observan bajo un prisma

convierte en el principal modelo de interpretación de la mitología pagana por la tradición cristiana. Véanse, P. Decharme, La critique des traditions religieuses chez les Grecs, des origines au temps de Plutarque, París, 1904, p. 371 ss., J. Seznec, Los dioses de la Antigüedad en la Edad media y el Renacimiento, Madrid: Taurus, 1983, p. 19 ss. (= París, 1940). En la Ilustración tal exégesis racionalista es practicada por Hume y Voltaire, el cual publicó en 1777 Dialogues de Evhémère.

94. En 1859 Bilbao se había incorporado a la masonería en Buenos Aires (Witker, op. cit., p. 315). 
favorable, desde los héroes de las Guerras Médicas y Alejandro Magno, a Homero, Heródoto, Demóstenes, Sófocles, Fidias y, sobre todo, los filósofos Sócrates y Platón. Capítulo aparte merece Aristóteles, cuya imagen negativa se explica a partir de su identificación con la escolástica y, en consecuencia, con el Antiguo Régimen. En cuanto a los próceres de Roma, Catón el joven demostraría la superioridad moral del vencido, frente a su vencedor, un ambivalente César, cuyos rasgos autoritarios legitiman la acción de Bruto, pero que es nombrado junto a Hércules, Alejandro y Colón entre los adelantados de la nueva era. Nerón, en fin, personifica la decadencia irremediable de la ciudad en la época imperial.

La mitología clásica también aporta figuras y episodios ejemplares. Los dioses, casi siempre en su advocación latina, sirven a Bilbao para simbolizar el advenimiento de la Razón (Minerva), el origen del Cosmos (Venus), las encrucijadas de la historia (Jano) o determinados caracteres (la voracidad del imperialismo cual nuevo Minotauro; el hombre-Mercurio). Particularmente relevante es el retrato de Júpiter-Zeus, identificado en varios contextos con el monarca absolutista, que intenta ocultar la Razón, esa Minerva liberada por Vulcano, y que representa un orden caduco que, aun venciendo, no convence al chileno. De ahí su defensa de los rebeldes mitológicos, como los Titanes, los Gigantes, Prometeo y Anteo. Entre todos los héroes antiguos mencionados en los ensayos sobresale Hércules, una figura no carente de notas sombrías pero cuyos «Trabajos» aluden a las fatigas y obstáculos de la Revolución, que intenta ahogar con sus manos infantiles las serpientes del despotismo, del Antiguo Régimen cuyos pilares ha de derribar.

Finalmente, si para gran parte de los exempla históricos y mitológicos cabe pensar ante todo en fuentes indirectas - desde sus lecturas de Voltaire y Lamennais, a las lecciones de Lastarria, Bello, y en particular de Quinet y Michelet, sin descartar recopilaciones de aforismos y anécdotas sobre grandes personajes-, no obstante es evidente que Bilbao maneja con soltura el latín, una lengua denostada en sus primeros escritos debido a su identificación con la cultura católico-medieval. Además de servirse frecuentemente de sentencias y tecnicismos del latín jurídico, bíblico y litúrgico, las citas poéticas revelan gran familiaridad con Virgilio y su aprecio por Lucano, en cuya épica parece encontrar nuestro romántico ilustrado un precedente de su apuesta por los héroes de la libertad. 
